\title{
Identifying superior spring wheat genotypes through diallel approaches
}

\section{Eduardo Stefani Pagliosa ${ }^{1}$, Giovani Benin ${ }^{1 *}$, Eduardo Beche ${ }^{2}$, Cristiano Lemes da Silva ${ }^{3}$, Anderson Simionato Milioli ${ }^{1}$ and Matheus Tonatto ${ }^{1}$}

\author{
${ }^{1}$ Universidade Tecnológica Federal do Paraná (UTFPR), Campus Pato Branco, Via do Conhecimento, Km 01, \\ Pato Branco, PR, CEP 85501-970, Brazil \\ ${ }^{2}$ Division of Plant Science, University of Missouri, Columbia, MO 65211, USA \\ ${ }^{3}$ Kansas State University, 204 Throckmorton Hall, 66506, Manhattan, Ks, USA
}

\section{*Corresponding author: benin@utfpr.edu.br}

\begin{abstract}
Diallel crosses enable plant breeders taking decisions concerning the parental choice for developing new varieties. Recently, a large number of methodological models have been reported. The objective of this study was to investigate the relationship between different methods of diallel analysis and their associations with grain yield performance in wheat (Triticum aestivum L.) segregating populations. In this study, four methods of diallel analysis were used to estimate the general (GCA) and specific (SCA) combining abilities: (a) Griffing, (b) Multivariate analyses of diallel crosses, (c) Restricted Maximum Likelihood / Best Linear Unbiased Prediction (REML/BLUP) and d) Genotypes and Genotypes x Environments biplot (GGE biplot). Six wheat cultivars were hybridized in a partial diallel scheme and later evaluated in the along with $15 \mathrm{~F}_{2}$ segregating populations. Griffing and REML/BLUP analysis produced equivalent results for GCA and SCA and are meaningful for identifying superior inbred lines. Multivariate diallel analysis suggested the best crosses for simultaneous improvement of traits. GGE biplot method is an effective method for visual comparisons of GCA and SCA effects. Conventional and innovative methods of diallel analysis are useful, complementary and should be applied in the selection of parents and superior crosses.
\end{abstract}

Keywords: GGE biplot; Griffing's diallel analysis; Multivariate diallel analysis; REML/BLUP; Triticum aestivum L.

Abbreviations: ATC_average tester coordinate; G_genotype; GCA_general combining ability; GE_genotype by environment interaction; GGE_genotype plus genotype by environment interaction; GY_grain yield; GYP_grain yield per plant; HW_hectoliter weight; NKS_number of kernels per spike; NPK_nitrogen, phosphorus and potassium; NSM_number of spikes per linear meter; NSS_number of spikelets per spike; PC_principal component; REML/BLUP_restricted maximum likelihood/best linear unbiased prediction; SCA_specific combining ability; SW_spike weight; TKW_thousand-kernel weight.

\section{Introduction}

Diallel analyses are important tools for identifying superior parents in order to development of new varieties in plant breeding programs. Recently a large number of methodological techniques have been reported and some of these approaches can be more informative than others.

The Griffing (1956) approach (all four methods) has been widely used to estimate genetic parameters (Biabani et al., 2012). This analysis is focused on partitioning the total variation of the data into GCA and SCA of parents and crosses, respectively. It also explains the potential of parents to produce superior progenies, associated with the magnitude of additive and non-additive gene action (Rainey and Griffiths, 2005; Bidhendi et al., 2011).

Diallel data contain typically complex patterns that are difficult to understand without the aid of some graphical display (Dehghani et al., 2012). Thus, recently Yan and Hunt (2002) suggested the GGE biplot technique to analyze the diallel. This methodology was developed originally to analyze multi-environment trial data (Yan, 2001). It allows extracting visual information to assess the performance of the GCA and SCA of each genotype, classify groups of parents with a similar genetic background (Yan and Hunt, 2002; Bertoia et al., 2006; Darvishzadeh et al., 2009). GGE biplot has the advantage of graphically displays the effects of genotype $(\mathrm{G})$ and genotype by environment (GE) interaction, and enhancing the ability to understand the patterns of the data in comparison with conventional methods of diallel analysis (Badu-Apraku et al., 2011; Dehghani et al., 2012).

Another prominent method to parental selection is the application of the mixed model approach (REML/BLUP). It allows estimating the variance components by REML and the predicting the genetic values using the BLUP (Henderson, 1975; Resende, 2002; Massman et al., 2013). BLUP predictors and REML estimators allow inferences regarding the additive and non-additive genetic effects related to the GCA and SCA (Piepho et al., 2008; Möhring et al., 2011). Moreover, the great advantage of this method is considering the genotype effects as random (Yang, 2007).

Plant breeders often must handle multiple traits in breeding programs. However, the analyses above-mentioned are performed on each trait separately. Hence, an alternative method is the use of multivariate diallel analysis, which allows combining multiple sources of information obtained from experimental plots. Further, it facilitates selection and permits the discrimination of the most promising populations (Jung et al., 2007; Benin et al., 2009). 
The objective of this study was to investigate the relationship between four different methods of diallel analysis (multivariate analysis, Griffing, REML/BLUP and GGE Biplot) and their associations with grain yield performance in wheat segregating populations.

\section{Results and Discussion}

\section{Analysis of variance and genetic effects}

The GCA and SCA Griffing's effects were significant for the all traits evaluated (Table 1), which implied the existence of significant genetic variation. The effects of the mean squares for the GCA were higher than the SCA effects for all traits, indicating that additive gene effects are controlling the traits (Blank et al., 2012). When additive gene action is predominant, selection during the early generations will be successful. In contrast, if additive gene effects are not present, selection should be performed in later generations when these effects would be fixed in the homozygous lines (Geleta and Labuschagne, 2006). The coefficients of variation ranged from 1.72 to 9.03 , indicating a high level of experimental precision.

Griffing multivariate analysis of variance also showed significant effects to GCA and SCA for all traits evaluated (Table 1). It implies that the wheat parents used in this study have complementary genes, and these traits can be assessed together in the diallel analysis. Significant effects of the GCA and SCA based on multivariate diallel analysis also were observed by Benin et al. (2009) and Nascimento et al. (2010) in wheat and sweet pepper, respectively.

\section{Principal components analysis}

The first three principal components (PC1: 44\%, PC2: 23\%, and PC3: $13 \%$ ) captured $80 \%$ of data variation in our study. Additionally, it was observed that certain traits were more related to specific PCs, which allows to infer about the magnitude and direction of the association of genetic effects (Ledo et al., 2003). PC1 showed a strong positive correlation ( $\mathrm{p}<0.05)$ with NKS (0.61), NSS (0.71), SW (0.92), GYP (0.91), HW (0.58), and GY (0.61). On the other hand, PC2 showed a negative correlation $(\mathrm{p}<0.05)$ with NSM $(-0.45)$ and NKS (-0.66), and a positive correlation with HW (0.63) and TKW (0.74). Further, PC3 showed a strong positive correlation with only NSM (0.82).

Thus, if the objective is to increase the NKS, NSS, SW, GYP and GY performance, the best SCA crosses should be chosen relative to $\mathrm{PC} 1$. However, to improve the traits HW and TKW, the crosses should be selected relative to PC2, and for NSM, the crosses should be selected by the scores of PC3.

\section{Mean performance, estimates of general and specific combining ability and association between the different methods of analysis}

High GCA estimates indicate a high-frequency flow of genes from parents to combinations and the presence of predominantly additive genes (Blank et al., 2012). Therefore, the choice of parents should be based in genotypes with a high GCA, which have greater chances of success to get superior crosses. The parents CD 150, BRS Pardela and Fundacep Cristalino had the highest observed and predicted GY averages and high GCA values according to the Griffing, multivariate (PC1) and REML/BLUP methods (Fig. 1). The agreement between these methods with respect to the GCA can be evaluated based on the magnitude of their associations
(Griffing $\times$ PC1 $=0.81$; Griffing $\times$ REML/BLUP $=0.99$ and PC1 $\times$ REML/BLUP = 0.89) $($ Table 3$)$. A positive correlation between Griffing and REML/BLUP (Valério et al., 2009; Nascimento et al., 2010; Baldissera et al., 2012) and between Griffing and GGE biplot (Darvishzadeh et al., 2009; Bocánski et al., 2011) was also observed by other authors.

The combination CD $150 \times$ Fundacep Cristalino presented the highest observed $\left(5521 \mathrm{~kg} \mathrm{ha}^{-1}\right)$ and predicted $(5437 \mathrm{~kg}$ $\mathrm{ha}^{-1}$ ) GY averages, and positive values for SCA according to the Griffing, multivariate (PC1, PC2 and PC3) and REML/BLUP analysis (Table 2). Additionally, the combinations CD 150 x CD 113, CD 117 x IPR 85, BRS Pardela x IPR 85 and Fundacep Cristalino x IPR 85, should be highlighted, since they presented positive SCA estimates. The use of the SCA by itself is not sufficient for the recommendation of a crossing. Selection should be based on crosses with superior SCA effects and involve at least one parent with a high GCA effects. This approach reinforces the use of crosses involving the parents CD 150, BRS Pardela and Fundacep Cristalino because they showed superior GY average performance and GCA according to the Griffing, multivariate (PC1), REML/BLUP (Fig. 1), and GGE biplot methods (Fig. 2A).

The GCA (0.99) and SCA (0.98) values were positively associated between Griffing and REML/BLUP methods (Table 3). PC1 x REML/BLUP (0.89) and PC1 x Griffing (0.81) also were positively related for GCA. The GCA estimative determined by Griffing and REML/BLUP analyses, were positively correlated with the observed $(0.90$ and 0.81 , respectively) and predicted $(0.93$ and 0.87 , respectively) GY (Table 3 ). It indicates that both methods are meaningful in order to identify potential parental lines for breeding programs. Only the observed averages were positively associated with the Griffing (0.60) and REML/BLUP (0.64) methods for SCA, suggesting that specific combinations can be selected according to genetic estimations obtained by these methods. The GCA and SCA estimative obtained using multivariate diallel analysis were not significantly correlated with the predicted and observed averages (Table 3 ). This result is likely due to the moderate association between PC1 (0.61) and GY (Table 1).

\section{Estimates of general and specific combining ability by $G G E$ biplot method}

The GCA and SCA effects, and the identification of the best crosses using the GGE biplot method, are shown in Fig. 2. The biplot for the grain yield data explained $82.4 \%(65.8 \%$ and $16.6 \%$ by $\mathrm{PC} 1$ and $\mathrm{PC} 2$, respectively) of the total variation of data (Fig. 2), which is sufficient to explain the whole performance variation of the parents and the hybrid combinations (Yan and Hunt, 2002). Similar results were found by Malla et al. (2010) and Boćanski et al. (2011). The parents BRS Pardela, Fundacep Cristalino and CD 150 are plotted on the positive end of the average tester coordinate (ATC) abscissa (Fig. 2A), indicating that they had positive GCA effects and the entries contributed to the improvement of their $\mathrm{F}_{2}$ combinations (Yan and Hunt, 2002; Malla et al., 2010). The results reported here, indicate similarities between the Griffing, multivariate (PC1), REML/BLUP and GGE biplot methods with respect to the GCA. Darvishzadeh et al. (2009), Malla et al. (2010) and Boćanski et al. (2011) also reported such similarities between the Griffing and GGE biplot analyses. The highest SCA estimates were obtained in the parents CD 113, CD 150 and Fundacep Cristalino (Fig. 2A). The SCA effects are associated with the parents instead of the $\mathrm{F}_{2}$ combinations in the GGE biplot analysis (Rastogi et 
Table 1. Mean squares and $F$ test of univariate variance analysis (ANOVA) and diallel variance analysis of Griffing, multivariate variance analysis, and Pearson correlation with agronomic traits and three principal components (PC1, PC2 and PC3), evaluated in spring wheat. Pato Branco, PR, Brazil, 2016.

\begin{tabular}{|c|c|c|c|c|c|c|c|c|c|}
\hline \multirow{2}{*}{ Source of variation } & \multirow{2}{*}{ D.F. } & \multicolumn{8}{|c|}{ Mean Squares / Traits / Griffing } \\
\hline & & $\mathrm{NSM}^{(1)}$ & NKS & NSS & SW & GYP & HW & TKW & GY \\
\hline Blocks & 2 & 177.63 & 24.88 & 0.006 & 0.084 & 0.073 & 0.62 & 5.24 & 268955 \\
\hline Genotypes $^{(2)}$ & 20 & $1997.79 * *$ & $44.26 * *$ & $1.632 * *$ & $0.164 * *$ & $0.123 * *$ & $10.82 * *$ & $51.61 * *$ & $548214 * *$ \\
\hline GCA & 5 & $2273.39 * *$ & $65.76 * *$ & $3.850 * *$ & $0.410 * *$ & $0.230 * *$ & $33.23 * *$ & $154.17 * *$ & $1436577 * *$ \\
\hline SCA & 15 & $1905.82 * *$ & $37.07 * *$ & $0.890 * *$ & $0.080 * *$ & $0.080 * *$ & $3.35^{*}$ & $17.41 * *$ & 252099* \\
\hline Error & 40 & 100.48 & 12.51 & 0.177 & 0.017 & 0.020 & 1.68 & 2.03 & 101030 \\
\hline Mean & & 111.08 & 41.68 & 17.09 & 2.25 & 22.41 & 75.66 & 36.39 & 4794.25 \\
\hline $\mathrm{CV}(\%)$ & & 9.03 & 8.50 & 2.47 & 5.90 & 4.59 & 1.72 & 3.91 & 6.63 \\
\hline \multirow{2}{*}{ Source of variation } & \multirow{2}{*}{ D.F. } & \multicolumn{8}{|c|}{ Mean Squares/ Multivariate analysis } \\
\hline & & \multicolumn{2}{|c|}{ Matrix of SQP } & $\Lambda$ & $\bar{F}$ & \multicolumn{2}{|c|}{ V1 } & V2 & $\mathrm{P}>\mathrm{F}$ \\
\hline GCA & 5 & \multicolumn{2}{|c|}{ SQP (GCA) } & 0.000 & 2352 & \multicolumn{2}{|c|}{40} & 146.63 & 0.000 \\
\hline SCA & 15 & \multirow{2}{*}{\multicolumn{2}{|c|}{$\begin{array}{l}\text { SQP (SCA) } \\
\text { SQP (Error) }\end{array}$}} & 0.000 & 155 & \multirow{2}{*}{\multicolumn{2}{|c|}{120}} & 247.14 & 0.000 \\
\hline Error & 40 & & & & & & & & \\
\hline \multirow{2}{*}{ Principal components } & VT & \multicolumn{8}{|c|}{ Pearson correlation / Traits } \\
\hline & $(\%)$ & $\mathrm{NSM}^{(1)}$ & NKS & NSS & SW & GYP & HW & TKW & GY \\
\hline PC1 & 44 & $0.16^{\mathrm{ns}}$ & $0.61 * *$ & $0.71 * *$ & $0.92 * *$ & $0.91 * *$ & $0.58 *$ & $0.41^{\mathrm{ns}}$ & $0.61 * *$ \\
\hline PC2 & 23 & $-0.45 *$ & $-0.66 * *$ & $-0.34^{\mathrm{ns}}$ & $0.22^{\mathrm{ns}}$ & $0.07^{\mathrm{ns}}$ & $0.63 * *$ & $0.74 * *$ & $-0.35^{\mathrm{ns}}$ \\
\hline PC3 & 13 & $0.82 * *$ & $-0.26^{\mathrm{ns}}$ & $0.11^{\mathrm{ns}}$ & $-0.15^{\mathrm{ns}}$ & $-0.24^{\mathrm{ns}}$ & $0.18^{\mathrm{ns}}$ & $0.30^{\mathrm{ns}}$ & $0.14^{\mathrm{ns}}$ \\
\hline
\end{tabular}

${ }^{(1)}$ NSM: number of spikes per linear meter; NKS: number of kernel per spike; NSS: number of spikelet per spike; SW: spike weight (grams); GYP: grain yield per plant (grams); HW: hectoliter weight; TKW: thousand kernel weight (grams); GY: grain yield $\left(\mathrm{Kg} \mathrm{ha}^{-1}\right)$. ${ }^{(2)}$ Parents and $\mathrm{F}_{2}$ populations. * and **: significant values at $1 \%$ and $5 \%$ probability, respectively, by the $F$ test. ${ }^{\text {ns }}$ : Not significant. DF= degrees of freedom; CV: coefficient variation; $\Lambda$ : estimate of Wilks value. PC1, PC2, and PC3: Principal component 1,2 , and 3, respectively. VT: Percentage of total variance explained by each mean component. For correlations: $* *$ and $*$ : significant values at $1 \%$ and $5 \%$ of probability, respectively, by the $t$ test. ${ }^{\text {ns: }}$. Not significant.
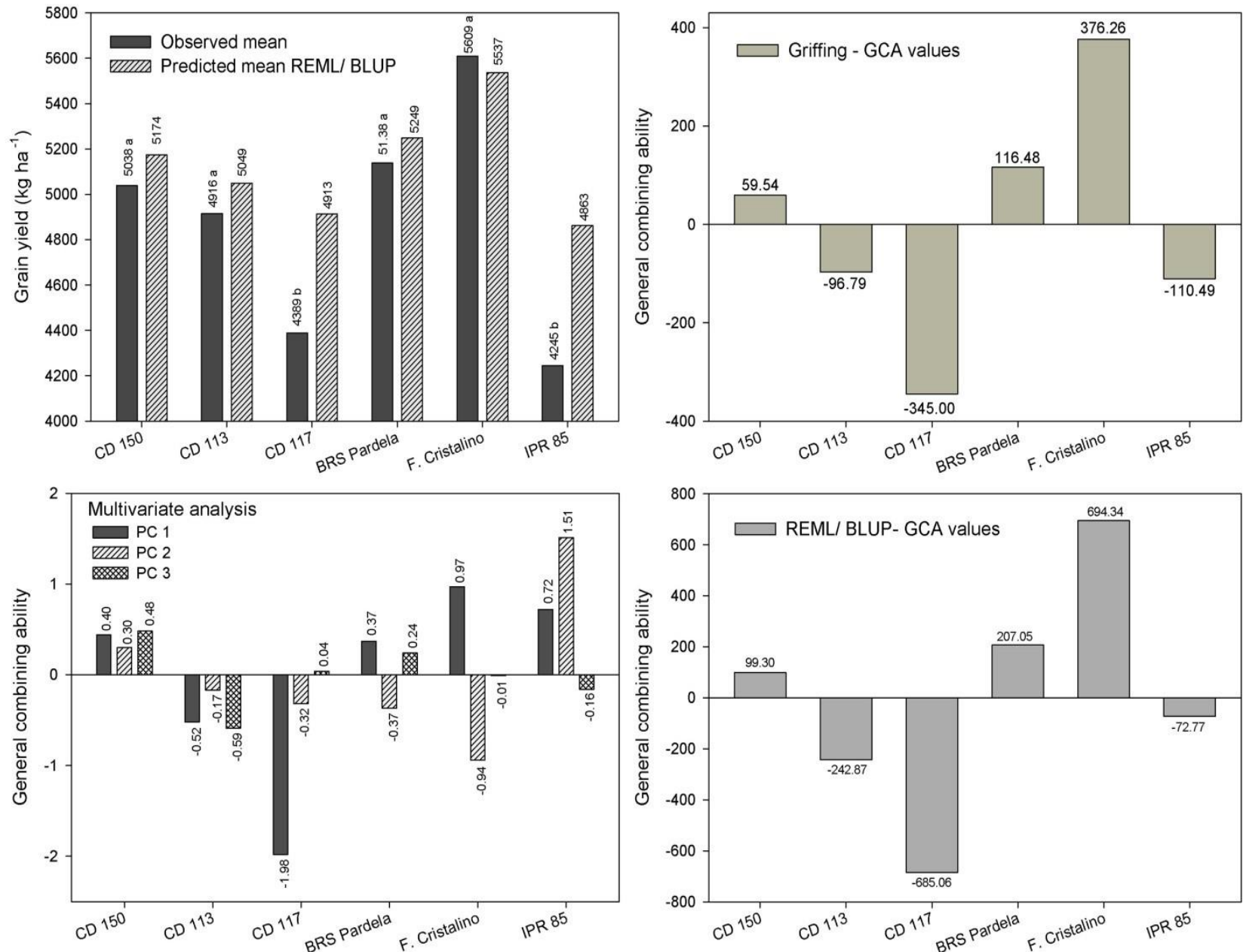

Fig 1. Mean observed and predicted, and general combining ability (GCA) for grain yield (GY) of six spring wheat parents by diallel analysis of Griffing, multivariate analysis (PC1, PC2, and PC3) and Restricted Maximum Likelihood / Best Linear Unbiased Prediction (REML/BLUP) analysis. Means followed by same letter do not differ by Scott-Knott test at 5\% probability. PC1: Principal component 1; PC2: Principal component 2; PC3: Principal component 3. Pato Branco, PR, Brazil, 2016. 
Table 2. Mean observed and predicted, and specific combining ability (SCA) for grain yield, for $15 \mathrm{~F}_{2}$ populations of spring wheat, through diallel analysis of Griffing, multivariate analysis (PC1, PC2 and PC3) and Restricted Maximum Likelihood / Best Linear Unbiased Prediction (REML/BLUP) analysis. Pato Branco, PR, Brazil, 2016.

\begin{tabular}{|c|c|c|c|c|c|c|c|}
\hline \multirow{3}{*}{ Crosses } & \multirow{3}{*}{$\begin{array}{c}\text { Mean } \\
\text { Observed }\end{array}$} & \multirow{3}{*}{$\begin{array}{c}\text { Mean } \\
\text { Predicted }\end{array}$} & \multicolumn{5}{|c|}{ SCA } \\
\hline & & & \multirow{2}{*}{ Griffing } & \multicolumn{3}{|c|}{ Multivariate } & \multirow{2}{*}{$\begin{array}{l}\text { REML/ } \\
\text { BLUP }\end{array}$} \\
\hline & & & & $\mathrm{PC}^{(2)}$ & $\mathrm{PC} 2$ & PC3 & \\
\hline $1-\mathrm{CD} 150 \times$ CD 113 & $4829 a^{(1)}$ & 5087 & 72.93 & 0.42 & -0.57 & 0.56 & 57.92 \\
\hline $2-\mathrm{CD} 150 \times \mathrm{CD} 117$ & $4098 b$ & 4845 & -410.45 & -0.21 & -0.65 & 0.91 & -181.72 \\
\hline 3 - CD 150 x BRS Pardela & $4918 \mathrm{a}$ & 5122 & -52.02 & 1.41 & -0.51 & -1.57 & -6.23 \\
\hline 4 - CD 150 x F. Cristalino & $5521 \mathrm{a}$ & 5437 & 291.76 & 0.76 & 0.89 & 0.98 & 162.73 \\
\hline 5 - CD $150 \times$ IPR 85 & $4590 \mathrm{~b}$ & 5030 & -152.67 & 0.30 & 0.98 & 0.00 & -94.34 \\
\hline $6-\mathrm{CD} 113 \times$ CD 117 & $4103 b$ & 4794 & -249.36 & -1.05 & 1.62 & 0.78 & -99.18 \\
\hline 7 - CD 113 x BRS Pardela & $4532 b$ & 4996 & -281.79 & 0.02 & 0.32 & -1.31 & -107.16 \\
\hline 8 - CD 113 x F. Cristalino & $4963 a$ & 5219 & -109.75 & 2.44 & -1.09 & -0.01 & -18.83 \\
\hline 9 - CD 113 x IPR 85 & $4523 b$ & 4913 & -63.66 & -0.04 & 0.07 & -0.40 & -45.63 \\
\hline 10 - CD 117 x BRS Pardela & $4484 b$ & 4888 & -81.25 & -0.96 & 0.23 & -0.96 & -25.76 \\
\hline 11 - CD 117 x F. Cristalino & $4457 b$ & 4965 & -367.64 & -0.03 & 0.18 & -0.45 & -152.62 \\
\hline 12 - CD 117 x IPR 85 & $4877 \mathrm{a}$ & 4938 & 538.70 & 1.50 & -0.95 & -0.70 & 224.40 \\
\hline 13 - BRS Pardela x F. Cristalino & $5246 a$ & 5363 & -40.19 & -1.10 & 0.97 & -0.34 & 8.34 \\
\hline 14 - BRS Pardela x IPR 85 & $5032 \mathrm{a}$ & 5154 & 232.47 & 1.17 & -0.09 & -0.20 & 87.89 \\
\hline 15 - Fundacep Cristalino x IPR 85 & $5160 \mathrm{a}$ & 5302 & 100.10 & -1.66 & 0.41 & 0.34 & 33.33 \\
\hline
\end{tabular}

${ }^{(1)}$ Means followed by same letter do not differ by Scott-Knott test at 5\% probability. ${ }^{(2)} \mathrm{PC} 1$ : Principal component 1; PC2: Principal component 2; PC3: Principal component 3.
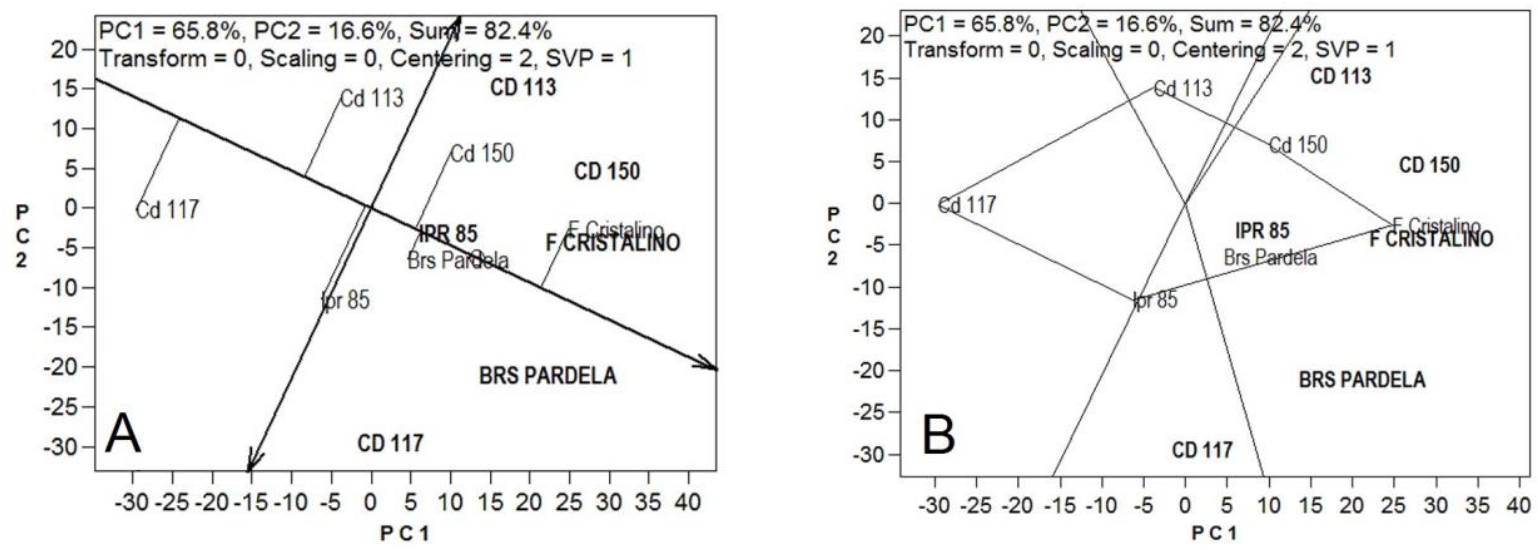

Fig 2. Diallel analysis by GGE Biplot of six spring wheat parents. (A) General combining ability (GCA) and specific combining ability (SCA) for grain yield (GY). (B) Best crosses for grain yield (GY). Genotypes are labeled with upper-case letters when viewed as entries and with lower-case letters when viewed as testers. The circle indicates the average tester in the figure A. Pato Branco, PR, Brazil, 2016.

Table 3. Pearson correlation for general combining ability (GCA) and specific combining ability (SCA) among Griffing analysis, multivariate analysis (PC1, PC2 and PC3), Restricted Maximum Likelihood / Best Linear Unbiased Prediction (REML/BLUP) analysis, mean observed and mean predicted. Pato Branco, PR, Brazil, 2016.

\begin{tabular}{|c|c|c|c|c|c|c|c|c|c|c|}
\hline & \multicolumn{10}{|c|}{ Grain yield (GY) } \\
\hline & \multicolumn{5}{|c|}{ GCA } & \multicolumn{5}{|c|}{ SCA } \\
\hline & \multirow[b]{2}{*}{ Griffing } & \multicolumn{3}{|c|}{ Multivariate } & \multirow{2}{*}{$\begin{array}{l}\text { REML/ } \\
\text { BLUP }\end{array}$} & \multirow[b]{2}{*}{ Griffing } & \multicolumn{3}{|c|}{ Multivariate } & \multirow{2}{*}{$\begin{array}{l}\text { REML/ } \\
\text { BLUP }\end{array}$} \\
\hline & & PC1 & PC2 & PC3 & & & $\mathrm{PC} 1$ & PC2 & PC3 & \\
\hline Griffing & 1 & $0.81 *$ & $-0.40^{\mathrm{ns}}$ & $0.25^{\mathrm{ns}}$ & $0.99 * *$ & 1 & $0.20^{\mathrm{ns}}$ & $-0.22^{\mathrm{ns}}$ & $0.05^{\mathrm{ns}}$ & $0.98 * *$ \\
\hline PC1 & & 1 & $0.19^{\mathrm{ns}}$ & $0.20^{\mathrm{ns}}$ & $0.89 *$ & & 1 & $-0.50^{\mathrm{ns}}$ & $-0.17^{\mathrm{ns}}$ & $0.20^{\mathrm{ns}}$ \\
\hline $\mathrm{PC} 2$ & & & 1 & $-0.05^{\mathrm{ns}}$ & $-0.28^{\mathrm{ns}}$ & & & 1 & $0.06^{\mathrm{ns}}$ & $-0.21^{\mathrm{ns}}$ \\
\hline PC3 & & & & 1 & $0.26^{\mathrm{ns}}$ & & & & 1 & $0.05^{\mathrm{ns}}$ \\
\hline REML/BLUP & & & & & 1 & & & & & 1 \\
\hline Mean Observed & $0.90^{*}$ & $0.50^{\mathrm{ns}}$ & $-0.72^{\mathrm{ns}}$ & $0.20^{\mathrm{ns}}$ & $0.81 *$ & $0.60 * *$ & $0.12^{\text {ns }}$ & $-0.13^{\text {ns }}$ & $0.03^{\text {ns }}$ & $0.64 * *$ \\
\hline $\begin{array}{l}\text { Mean Predicted } \\
\text { (REML/BLUP) }\end{array}$ & $0.93 * *$ & $0.54^{\mathrm{ns}}$ & $-0.70^{\mathrm{ns}}$ & $0.28^{\mathrm{ns}}$ & $0.87 *$ & $0.32^{\mathrm{ns}}$ & $0.04^{\mathrm{ns}}$ & $-0.04^{\mathrm{ns}}$ & $0.10^{\mathrm{ns}}$ & $0.40^{\mathrm{ns}}$ \\
\hline
\end{tabular}


al., 2011; Shariff and Motlagh, 2011). Thus, emphasis should be placed on the crosses that have the parents Fundacep Cristalino and CD 150 because they have higher GCA and SCA estimates according to the GGE biplot, Griffing, multivariate (PC1) and REML/BLUP methods.

The polygon view of the biplot describes the interaction between the entry and the tester (Fig. 2B). Polygon is drawn by joining the outermost entries, which become the vertices of the polygon, to the origin. Perpendicular lines drawn from the origin to the sides of the polygon divide the diagram into different entry sectors. Any tester(s) falling into a given sector forms a superior hybrid exhibiting heterosis from a cross between the tester and the vertex entry. If the tester and vertex entry of the same genotype exist together in any given sector, then the parent must be superior to any hybrid formed with the vertex entry (Malla et al., 2010). Thus, it could be concluded that the best crosses for GY are Fundacep Cristalino x CD 150, CD 150 x CD 113, BRS Pardela x IPR 85 and BRS Pardela $x$ Fundacep Cristalino (Fig. 2B). These crosses were identified as having the best SCA based on the multivariate (PC1), Griffing and REML/BLUP analyses, showing similarity among these methods, except for the combination BRS Pardela $x$ Fundacep Cristalino. In contrast, the hybrid combination CD 117 x IPR 85 was recognized as the highest SCA based on the Griffing (538.7), REML/BLUP (224.4) and multivariate (PC1: 1.5) analyses, is not considered in the GGE biplot method (Fig. 2B).

Accurate GCA and SCA estimates of parents can increase the breeding efficiency. GGE biplot graphical analysis provides information about the effect of the parents on the GCA and SCA, and the standard group of similar genotypes (Dehghani et al., 2012). However, the graphical display of the SCA effects represents the tendency of a parent to produce superior $\mathrm{F}_{2}$ combinations in only certain crosses but not in all cases (Yan and Hunt, 2002; Yan and Kang, 2003). As a result, this method cannot be used by itself.

The results suggest that the Griffing and REML/BLUP methods provide similar information and are equally efficient to select parents and hybrid combinations, and are meaningful in order to identify potential breeding genotypes. Griffing's methods allow testing the significance (Yan and Hunt, 2002), however, the fixed effects model inferences are limited to the specific results of locations and genotypes. On the other hand, with REML/BLUP model (random effects), assumptions can be extrapolated to a wider set of environments (Valério et al., 2009; Gowda et al., 2013), allowing consistent prediction of single-crosses and hybrid performance.

\section{Materials and Methods}

\section{Plant materials and experimental conduction}

Six wheat cultivars (CD 150, CD 113, CD 117, BRS Pardela, Fundacep Cristalino and IPR 85) were crossed using a complete diallel mating design without reciprocals, totalizing 15 hybrid combinations. The $F_{1}$ seeds from each single cross were sown in the greenhouse to obtain the $F_{2}$ population.

The field experiment was carried out in the growing season of $2011\left(26^{\prime} 10^{\prime} \mathrm{S} ; 52^{\prime} 41^{\prime} \mathrm{W}\right)$. Seeds harvested from $\mathrm{F}_{1}$ plants $\left(\mathrm{F}_{2}\right.$ combinations) and the six parents were sown in a complete randomized block design with three replications. The experimental plots consisted of five rows that were $3 \mathrm{~m}$ long, with $0.20 \mathrm{~m}$ between rows with density of 300 seeds $\mathrm{m}^{-}$ ${ }^{2}$. Base fertilization consisted of $350 \mathrm{~kg} \mathrm{ha}^{-1} \mathrm{NPK}$ (5-20-20) with additional of $60 \mathrm{~kg} \mathrm{ha}^{-1}$ of nitrogen applied at early tillering stage. Other factors that could affect the expression of potential crop yield such as pests, diseases and weeds were managed according to the brazilian technical recommendations for wheat crop (RCBPTT, 2010).

\section{Traits evaluated}

The following traits were evaluated: number of spikes per linear meter (NSM); number of kernels per spike (NKS); number of spikelets per spike (NSS); spike weight, in grams (SW); grain yield per plant, in grams (GYP), calculated based on the average of 10 spikes harvested at random from each plot; thousand-kernel weight, in grams (TKW), estimated based on the weight of 200 grains and three counts per experimental unit and extrapolated to a thousand kernels. The hectoliter weight in $\mathrm{kg} \mathrm{hL}^{-1}(\mathrm{HW})$, and the grain yield (GY), were determined by harvesting the plots and adjusting the values to $13 \%$ moisture, and then converted to $\mathrm{kg} \mathrm{ha}^{-1}$.

\section{Statistical analysis}

The assumptions of data normality and homogeneity of variance were tested using Lilliefors' and Bartlett's tests, respectively. Diallel analysis was carried out via the following four methods:

a) Griffing diallel analysis (1956), model 2: The statistical model was represented by the equation $Y_{i j}=\mu+g_{i}+$ $g_{j}+s_{i j}+\varepsilon_{i j}$, where $Y_{i j}$ is the average value of the hybrid $i j(i \neq j)$ or parent $(i=j)(i, j=1,2, \ldots p) ; \mu$ is the general average; $g_{i}$ and $g_{j}$ are the effects of the GCA of the $i$ and $j$ parent, respectively; $s_{i j}$ is the effect of SCA for crosses among the parents of order $i$ and $j$; and $\varepsilon_{i j}$ is the average experimental error. The software Genes (Cruz, 2006) was used to analyze the data.

b) REML/BLUP: Model number 36 was applied for complete blocks and one plant per plot using unrelated parents (Resende, 2002). The statistical model is: $y=X r+Z a+$ $W f+e$, where $y$ is the data vector; $r$ is the vector of the replication effects (assumed to be fixed) added to the general mean; $a$ is the vector of individual additive genetic effects (assumed to be random); $f$ is the vector of the full-sib line dominance effects (random); $e$ is the vector of errors or residuals (random); and capital letters represent the incidence matrices for these effects. The software SelegenREML/BLUP (Resende, 2002) was used for the data analysis.

c) GGE Biplot: In the GGE analysis the terms average yield and stability are correspondent to GCA and SCA of the parents, respectively. The model used for biplot analysis of diallel data is the tester-centered principal component analysis, following the model described by Yan and Kang (2003): $\hat{\mathrm{Y}}_{i j}-\mu-\beta_{j}=g_{\mathrm{i} 1} e_{\mathrm{lj}}+g_{\mathrm{i} 2} e_{2 \mathrm{j}}+\varepsilon_{i j}$, where $\hat{\mathrm{Y}}_{i j}$ is the expected value of the cross between entry $i$ and tester $j ; \mu$ is the grand mean; $\beta_{j}$ is the main effect of tester $j ; g_{\mathrm{il}}$ and $e_{\mathrm{lj}}$ are called the primary effects for entry $i$ and tester $j$, respectively; $g_{\mathrm{i} 2}$ and $e_{2 \mathrm{j}}$ are the secondary effects for entry $i$ and tester $j$, respectively; and $\varepsilon_{i j}$ is the residue not explained by the primary and secondary effects. A biplot is constructed by plotting $g_{i l}$ against $g_{i 2}$ and $e_{1 j}$ against $e_{2 j}$ in a single scatter plot. This analysis was performed with GGE biplot software (Yan, 2001).

d) Diallel multivariate analysis: The diallel analysis were initially performed using univariate analysis employing the complete diallel method, without reciprocals, according to model 2 of the Griffing method (1956), with the estimation of GCA and SCA effects. The principal component analysis were performed using the method described by Cruz and 
Regazzi (1997). After determining the number of principal components, which involved a minimum of $80 \%$ of the available variation, the scores and relative importance were estimated for each principal component. Then, a diallel analyses of the component scores was performed to obtain the combining ability effect for each component (Ledo et al., 2003). The hypothesis of equality of genetic effects for the multivariate diallel analysis was assessed using the Wilks test with an $\mathrm{F}$ approximation (Harris, 1975). The most important traits for determining the first and second principal components were identified based on the Pearson's correlation between the principal components and the traits average.

The associations between genetic parameters using the Griffing, REML/BLUP and multivariate diallel analysis were determined using Pearson's correlations.

\section{Conclusion}

Griffing and REML/BLUP analyses produced redundant results to GCA and SCA, and are meaningful to identify superior inbred lines. Multivariate diallel analysis point out the best crosses for simultaneous improvement of traits. GGE biplot analysis provides visual details and indicates behavioral patterns for parents and hybrid combinations, which help to select superior genotypes in wheat breeding programs. Conventional and innovative methods of diallel analysis are useful and complementary to identify parents and crosses that could be applied efficiently in wheat breeding programs.

\section{Acknowledgments}

To Coordenação de Aperfeiçoamento de Pessoal de Nível Superior (Capes) for financial support.

\section{References}

Badu-Apraku B, Akinwale RO, Menkir A, Obeng-Antwi K, Osuman AS, Coulibaly N, Onyibe JE, Yallou GC, Abdullai MS, Didjera A (2011) Use of GGE biplot for targeting early maturing maize cultivars to mega-environments in west Africa. Afr Crop Sci J. 19:79-96.

Baldissera JNC, Bertoldo JG, Valentini G, Coan MMD, Rozeto DS, Guidolin AF, Coimbra JLM (2012) Using the best linear unbiased predictor (BLUP) for predicting hybrid beans. Biosci J. 28:395-403.

Benin G, Silva GO, Pagliosa ES, Silva CL, Signorini A, Beche E, Capelin MA (2009) Capacidade de combinação em genótipos de trigo estimada por meio de análise multivariada. Pesqui Agropecu Bras. 44:1145-1151.

Bertoia L, López C, Burak R (2006) Biplot analysis of forage combining ability in maize landraces. Crop Sci. 46:1346-1353.

Biabani A, Rafii MY, Saleh G, Shabanimofrad M, Latif MA (2012) Combining ability analysis and evaluation of heterosis in Jatropha curcas L. F1-hybrids. Aust J Crop Sci. 6:1030-1036.

Bidhendi MZ, Choukan R, Darvish F, Mostafavi K, Hervan EM (2011) Determination of combining abilities and heterotic patterns of fourteen medium to late maturing Iranian maize inbred lines using diallel mating design. Afr J Biotechnol. 10:16854-16865.

Blank AF, Rosa YRS, Carvalho Filho JLS, Santos CA, ArrigoniBlank MF, Niculau ES, Alves PB (2012) A diallel study of yield and essential oil constituents in basil (Ocimumbasilicum L.). Ind Crops Prod. 38:93-98.

Boćanski J, Nastasić A, Stanisavljević D, Srećkov Z, Mitrović B, Treskić S, Vukosavljev M (2011) Biplot analysis of diallel crosses of ns maize inbred lines. Genetika. 43:277-284.

Cruz CD (2006) Programa genes: análise multivariada e simulação, 1st edn. UFV, Viçosa.
Cruz CD, Regazzi AJ (1997) Modelos biométricos aplicados ao melhoramento genético, 2nd edn. UFV, Viçosa.

Darvishzadeh R, Bernousi I, Kianipoormohammad S, DechampGuillaume G, Sarrafi A (2009) Use of GGE biplot methodology and griffing's diallel method for genetic analysis of partial resistance to phoma black stem disease in sunflower. Acta Agr Scand B-S P. 59:485-490.

Dehghani H, Feyzian E, Jalali M, Rezai A, Dane F (2012) Use of GGE biplot methodology for genetic analysis of yield and related traits in melon (Cucumis melo L.). Can J Plant Sci. 92:77-85.

Geleta LF, Labuschagne MT (2006) Combining hability and heritability for vitamin $\mathrm{C}$ and total soluble solids in pepper (Capsicum annuum L.). J Sci Food Agr. 86:1317-1320.

Gowda M, Zhao Y, Maurer HP, Weissmann EA, Wurschum T, Reif JC (2013) Best linear unbiased prediction of triticale hybrid performance. Euphytica. 191:223-230.

Griffing B (1956) Concept of general and specific ability in relation to diallel crossing systems. Aust J Biol Sci. 9:462-493.

Harris RJ (1975) A primer of multivariate statistics, 1st edn. Academic, New York.

Henderson CR (1975) Best linear unbiased estimation and prediction under a selection model. Biometrics. 31:423-447.

Jung MS, Vieira EA, Silva GO, Brancker A, Nodari RO (2007) Capacidade de combinação por meio de análise multivariada para caracteres fenotípicos em maracujazeiro-doce. Pesqui Agropecu Bras. 42:689-694.

Ledo CAS, Ferreira DF, Ramalho MAP (2003) Análise de variância multivariada para os cruzamentos dialélicos. Cienc Agrotec. 27:1214-1221.

Malla S, Ibrahim AMH, Glover KD, Berzonsky WA (2010) Combining ability for Fusarium head blight resistance in wheat (Triticum aestivum L.). CBCS. 5:116-126.

Massman JM, Gordillo A, Lorenzana RE, Bernardo R (2013) Genome wide predictions from maize single-cross data. Theor Appl Genet. 126:13-22.

Möhring J, Melchinger AE, Piepho HP (2011) REML-based diallel analysis. Crop Sci. 51:470-478.

Nascimento IR, Maluf WR, Gonçalves LD, Faria MV, Resende JTV, Nogueira DW (2010) Capacidade combinatória de linhagens de pimentão a partir de análise dialélica multivariada. Acta Sci Agron. 32:235-240.

Piepho HP, Möhring J, Melchinger AE, Büchse A (2008) BLUP for phenotypic selection in plant breeding and variety testing. Euphytica. 161:209-228.

Rainey KM, Griffiths PD (2005) Diallel analysis of yield components of snap beans exposed to two temperature stress environments. Euphytica. 142:43-53.

Rastogi A, Mishra BK, Srivastava M, Siddiqui A, Shukla S (2011) Biplot approach for identification of heterotic crosses in linseed (Linum usitatissimum L.). J Bot. 10:1-7.

RCBPTT - Reunião da comissão brasileira de pesquisa de trigo e triticale (2010). Informações técnicas para a safra 2010: trigo e triticale. In: Comissão brasileira de pesquisa de trigo e triticale. Cascavel, Paraná.

Resende MDV (2002) Software selegen - REML/BLUP. Embrapa Floresta, Curitiba.

Shariff P, Motlagh MRS (2011) Biplot analysis of diallel crosses for cold tolerance in rice at the germination stage. Crop Pasture Sci. 62:169-176.

Valério IP, Carvalho FIF, Oliveira AC, Souza VQ, Benin G, Schmidt DAM, Ribeiro G, Nornberg R, Luch H (2009) Combining ability of wheat genotypes in two models of diallel analyses. Crop Breed Appl Biot. 9:100-107.

Yan W (2001) GGE biplot - a windows application for graphical analysis of multi-environment trial data and other types of twoway data. Agron J. 93:1111-1118.

Yan W, Hunt L (2002) Biplot analysis of diallel data. Crop Sci. 42:21-30.

Yan W, Kang MS (2003) GGE biplot analysis: a graphical tool for breeders, geneticists, and agronomists, 1st edn. CRC Press, Boca Raton.

Yang RC (2007) Mixed-model analysis of crossover genotypeenvironment interactions. Crop Sci. 47:1051-1062. 